\title{
Deficit, Decay and Deprioritization of Transport Infrastructure in Nigeria: Policy Options for Sustainability
}

\author{
Lionel Effiom ${ }^{1} \&$ Peter Ubi ${ }^{1}$ \\ ${ }^{1}$ Department of Economics, University of Calabar, Nigeria \\ Correspondence: Lionel Effiom, Department of Economics, University of Calabar, Nigeria. E-mail: \\ leoeff2002@yahoo.com
}

Received: November 29, 2015

Accepted: December 23, 2015

Online Published: February 25, 2016

doi:10.5539/ijef.v8n3p55

URL: http://dx.doi.org/10.5539/ijef.v8n3p55

\begin{abstract}
It is common knowledge that Nigeria's road infrastructure, and indeed the general infrastructure of sub-Saharan Africa, is in a most despicable condition. This paper formalises this observation by providing current data to support the hypothesis. By deploying descriptive and theoretical methodological approaches, it demonstrates that road infrastructure is not only deteriorating but also suffers from a twin evil of deficit and deprioritisation in the public sector's preferential scale-a state of indifference of sorts. Long and short term policy choices have to be made to urgently address the issue. In the short term, infrastructure concessions, public private partnerships (PPP), pension funds, sovereign wealth fund, savings from reduction in fuel subsidies, leveraging on the Africa Growth and Opportunity Act (AGOA) mechanism-are part of the portfolio of choices that government can readily choose from. In the long term however, the paper recommends increase in the statutory allocation to the states and local governments which would ensure that component units of the federation control more resources to deploy and develop infrastructure in their immediate domain.
\end{abstract}

Keywords: deficit, decay, deprioritisation, road-infrastructure

\section{Introduction}

Infrastructure has been conceptualised by Akinwale (2010) and Frishmann (2007) as the resource systems that have been harnessed for the development of the society. These include (1) transportation systems, such as highway systems, railways, airline systems, and ports; communication systems, such as telephone networks and postal services; governance systems, such as court systems; and basic public services and facilities, such as schools, sewers, and water systems. In the Frishmann terminology they are referred to as traditional infrastructure, as distinct from non-traditional resources like environmental resources, such as lakes, the atmosphere, and ecosystems; (2) information resources, such as basic research, abstract ideas, and operating systems; and (3) Internet resources, such as interconnected computer networks and protocols that enable interconnection, interoperability, and data transfer. They are the bedrock upon which any sustainable development can take place.

Todaro and Smith (2009) provide a more comprehensive definition of the term to mean the underlying amount of physical and financial capital embodied in roads, railways, waterways, airways, and other forms of transportation and communication, plus water supplies, financial institutions, electricity, and public services such as health and education. In other words it is unthinkable to initiate the process of economic development without establishing these key substructures. Economic development acquires its pace and diversity depending on the quantum of infrastructure available in an economy. Farmers must find a way of conveying their agricultural produce from the hinterland farms to the towns and cities; the artisan in the suburbs and villages, the small and medium scale entrepreneurs, need energy to run their simple tools and machines; telecommunication providers must rely on the existing local and national power infrastructure to supply services to millions of users; firms, businesses and industrialists all depend on the interrelated systems and network of resources to add to the gross domestic product of the country. Where these resources are either deficient, or in a state of decay, or out rightly non-existent, the cost of doing business increases, with unsavoury implications for prices of final consumer goods - especially where demand is inelastic.

Ubi et al. (2011) are of the opinion that efficient infrastructure development underlies the integration of the national economy and helps in spreading its benefits. This suggests that existence of minimal levels of 
infrastructure in an economy results in positive multiplier effects on the aggregate level of economic activities. They act as an incentive to attract industrial investment to an economy. For instance, South Africa successfully bided and hosted the 2010 FIFA World Cup because it had the necessary infrastructure to support the tournament. Such a dream is unrealistic for Nigeria, even though she apparently has more resources than South Africa.

The dearth of infrastructure to drive economic growth is not Nigeria-specific; it is an African problem, or more generally a problem characteristic of developing economies. Agénor (2010) maintains that in Sub-Saharan Africa in particular, only 16 percent of roads are paved, and less than one in five Africans has access to electricity. Transport costs are the highest in the world and act as a significant constraint on trade expansion. Similarly, Yoshino (2008) found that poor quality of public infrastructure-measured in terms of the average numbers of days per year for which firms experience disruptions in electricity-has an adverse effect on exports in sub-Saharan Africa. In Rwanda, farmers receive only 20 percent of the price of their coffee as it is loaded onto ships in Mombasa; the other 80 percent disappear into the costs of poor roads (as well as red tape) between Rwanda and Kenya. Studies, such as that by the Infrastructure Consortium of Africa (ICA), have shown that poor road, rail and harbour infrastructure adds $30-40 \%$ to the costs of goods traded among African countries.

What is the actual condition of Nigeria's road infrastructure, a critical component of the overall transportation infrastructure relevant for the development of the real sector? What gaps exist between actual and desired quantum of road infrastructure necessary to achieve the target envisioned in Nigeria's Vision 20:2020. Has there been a deliberate plan or policy by government to address these gaps? How effective have these policies been? Could there be alternative financing models especially in view of dwindling national revenue due to leakages of corruption and red tape? We deliberately concentrate on the dimensions and dynamics of road infrastructure because it has been estimated that road infrastructure constitutes more than $95 \%$ of Nigeria's passenger and freight services. It is the one major means of transportation for the average Nigerian. Our thesis is three-fold. First, that there has been a systematic decay, underinvestment (deprioritisation) and a yawning deficit in road infrastructure provision in Nigeria over the years in spite of the surge in urbanisation and demographic pressures. This undermines the efficiency of the transport subsector to effectively promote growth of the real sector of the economy. Second, we argue that the quality of roads constructed as well as institutionalised corruption in the government bidding process are major binding constraints on the development of road infrastructure in Nigeria. In effect, the social marginal utility for every naira spent on road construction is reduced and lost to institutional red tape, rent-seeking, and corruption. Thirdly, that conventional funding pattern within the budget framework is ineffective and unsustainable in view of the huge funding needs of the subsector and government fiscal receipts.

Following this introduction, section two situates the study within its proper theoretical orbit. Section three presents stylised facts on evidence of decay and deficit in road infrastructural provision in Nigeria. In section 4 policy responses of government are reviewed to underline the fact of deprioritisation of infrastructure provision. Sections 5 and $6 \mathrm{x}$-rays the infrastructure gap and the financing options respectively, while Section 7 concludes the paper. The methodology adopted is both theoretical and descriptive.

\section{Theoretical Considerations}

Infrastructure, whether they are transport, telecommunications, energy, education or other public utilities, has been well documented in the literature to have a positive and significant relationship with economic growth. Rise in telecommunications infrastructure in the United States, for instance, has been shown by Jorgenson (2001) to contribute more than one-half of the recent increase in the US economic growth. Similarly, Kraemer and Dedrick (2001) using data from 43 countries, upheld the view that the growth in IT investment is correlated with productivity growth. In Nigeria a study by Tella et el. (2007) found that main landline and cell phone penetration had significant effects on economic growth, when controlled for the effects of capital and labour.

Agénor (2010) presents a theory of development based on public infrastructure as the main engine of growth. This theory discountenances human capital accumulation and endogenous technological progress. Thus in the model, the growth rate depends on the interactions between infrastructure, health, and savings. Infrastructure raises the economy's ability to produce health services; in turn, greater access to health services enhances workers' productivity, and therefore output. Thus, the accumulation of human capital results not from the acquisition of knowledge, but from better quality of effective labour. Unlike endogenous growth models in the Uzawa-Lucas tradition, this model assumes that knowledge is embodied in workers, as opposed to books and libraries. In addition, improvements in health raise incentives to save. This effect occurs not through its direct impact on life expectancy given that the representative household in the model is infinitely-lived-but by reducing the degree of impatience, or equivalently, preference for the present.

In other words as a result of network effects, the degree of efficiency of infrastructure is nonlinearly related to 
the stock of public capital itself. This in turn may generate multiple equilibria. Provided that governance is adequate enough to ensure a sufficient degree of efficiency of public investment outlays, an increase in the share of spending on infrastructure (financed by a cut in unproductive expenditure or foreign grants) may facilitate the shift from low growth equilibrium, characterized by low productivity and low savings, to a high growth steady state.

Another theory relevant to the present discourse is the Hirschmann theory of unbalanced growth. It maintains that creating imbalances in the system is the best strategy for growth. Owing to the lack of availability of resources in the less developed countries, the little that is available must be used efficiently. Accordingly strategic sectors in the economy should get priority or precedence over others where income is concerned. The theory argues that the process of accelerating the process of growth should be initiated with investment made in the key sectors of the economy by the government. It is the inducement or pressure generated by some initial investment that calls for subsequent investment in other activities or production.

The unbalanced growth theory of Hirschman, akin to the big push theory, underlines the significance of basic industries in the process of growth. The strategy of unbalanced growth generates economies of large scale production. Establishing key industries calls for the establishment of ancillaries, generating all round increase in income and employment. Unbalanced growth generates pulls and pressures in the system, calling for new inventions and innovations. Economic growth follows the course of imbalances by generating positive externalities and complementarities in demand. Competitions, tensions as well as inducements are the inevitable outcome of the unbalanced growth, and the more these exist, the greater the prospects of growth. The government can deliberately create these imbalances by investment either in Social Overhead Capital (SOC) or in Directly Productive Activities (DPA). Doing all at the same time (i.e. pursuing a balanced path) may not be feasible in view of the scarcity of resources.

Recent researches (Agénor, 2009; Agénor \& Kyriakos, 2006; Wagstaff \& Cleason, 2004; Wang, 2003) have also demonstrated that infrastructure may also affect growth indirectly through a variety of channels, most notably by affecting health outcomes. These studies found out that access to clean water and sanitation helps to improve health and thereby productivity. By reducing the cost of boiling water, and reducing the need to rely on smoky traditional fuels (such as wood, crop residues, and charcoal) for cooking, access to electricity also helps to improve hygiene and health-in the latter case by reducing indoor air pollution and the incidence of respiratory illnesses.

The literature also dichotomises infrastructure into social or soft core infrastructure and physical or hard core infrastructure. The former consists of provision of health care and education, types of governance, accountability and property rights and is often viewed as the driving force of industrial cum economic activity. Hard core infrastructure pertains to physical structures and comprises telecommunication, power, transportation, water supply and sewage.

\section{The Twin Evils of Infrastructure Decay and Deficit in Nigeria}

Infrastructural deficit and decay, whether of transportation or any other component of the social overhead, has assumed a legendary dimension in Nigeria. Edame et al. (2011) argue that several government policies have led to infrastructural decay and poor industrial development. They however do not mention the specific government policies responsible for this decay. So decrepit are the roads that in recent times it has become the subject of industrial action by Petroleum and Natural Gas Workers of Nigeria (PENGASON) who are peeved that their tanker vehicles have become victims of poor road infrastructure. These strikes often assume a state or regional as well as national dimension. A concrete instance of decay is the River Niger Bridge which was built in 1965 under the then colonial administration. The bridge is significant because it connects the south and eastern parts of the country to the other parts. Without it the commercial and manufacturing activities in Aba, Onitsha and Nnewi is doomed. Currently, the bridge is at the brink of caving in and has become a nightmare to commuters mainly due to poor maintenance, overuse, and frequent subjection to overbearing deadweight. This is not surprising as it has been estimated that roads account for transporting $95 \%$ of Nigeria's national passenger and freight services. Consequently, many Nigerian roads undergo failures which in many cases become perennial.

Another sordid tale in the history of poor road infrastructure is the deplorable condition of the $338 \mathrm{~km}$ East-West road in the South-South region of Nigeria. An inheritance from the military dispensations, the completion of this road is believed to have the potential of opening up access to investment and the much-needed development in the region. With the largest road network in West Africa and the second largest South of the Sahara (Aderamo, 2012), Nigerian roads are poorly maintained and are often cited as a cause for the country's high rate of traffic fatalities. According to El-Ruffai (2011) 17.6 percent of these roads are owned by the Federal Government, while 
the various state governments own 15.7 percent of the network and the remaining 66.7 percent are local and rural roads controlled by the local government councils. With a potential for high tax revenue, Federal roads carry 70 percent of the total freight traffic across the country annually. This explains why Nigerian roads do not last as long as they should.

Aderamo (2012) maintains that about $70 \%$ of public sector investments in the transport sector have on the average been on highway. The estimated total road length in 1946 was $11,427 \mathrm{Km}$ of Trunk A and Trunk B roads and $0,225 \mathrm{Km}$ of feeder roads. By 1985 , road length had increased to $114,800 \mathrm{Km}$ and as at January, 1996, the road length totalled 193, 200Km. However, by 2012, the Urban Development Bank put this figure at 195,000km, a marginal increase indeed. Out of this figure $32,100 \mathrm{~km}(17.0 \%)$ can be classified under federal or trunk roads; $30,500 \mathrm{Km}(16.0 \%)$ under state roads and $130,600 \mathrm{Km}(67.0 \%)$ under local government roads. Federal roads provide linkages between state capitals and other major towns; state roads link towns to other settlements and local government roads link relatively smaller communities. Over 80 percent of Nigerian roads are managed by States and local government authorities, who often have weak capacity to design and execute public expenditure programs. Buhari (2000) and the Urban Development Bank (2013), estimate that about 50 percent of the country's overall road network is in a poor state, while $20 \%$ of the state roads were in reasonably good condition as at June, 1996 and only an estimated 5\% of the total rural roads were freely motorable. The poor state of Nigeria's road network may be attributed to historic low levels of investments in road infrastructure as well as weak contracting procedures and poor planning of road construction projects and inadequate maintenance.

A holistic view of this menace can be readily seen from Table 1 . Of the over $37,000 \mathrm{~km}$ of federal roads across Nigeria, only 25 percent of it have been adjudged good by the federal agency in charge of road repairs-Federal Roads Maintenance Agency (FERMA). An aggregate of 47 percent is in a bad state. While the North of the country has the luxury of having the largest number of road length, two of its sub-regions-the North East and Central have the largest percentage points of bad roads -45 percent each. Again the North West region plays host to the largest percentage points of good roads and the lowest percentage points of bad roads. This overall grim picture undoubtedly accounts for the increasing number of road accidents, high transportation and production costs, as well as the general state of underdevelopment in Nigeria.

Table 1. Status of federal roads in Nigeria as @ 31 ${ }^{\text {st }}$ March 2012

\begin{tabular}{|c|c|c|c|c|c|}
\hline REGIONS & $\begin{array}{c}\text { TOTAL } \\
\text { LENGTH } \\
\text { (KM) }\end{array}$ & $\begin{array}{l}\text { GOOD ROADS(KM) } \\
\text { (\% of Total length) }\end{array}$ & $\begin{array}{l}\text { FAIR ROADS(KM) } \\
\text { (\% of Total length) }\end{array}$ & $\begin{array}{c}\text { POOR } \\
\text { ROADS(KM) } \\
\text { (\% of Total length) }\end{array}$ & $\begin{array}{c}\text { BAD ROADS } \\
\text { (KM) } \\
\text { (\% of Total length) }\end{array}$ \\
\hline S/EAST & 3,357 & $\begin{array}{l}1067.9 \\
(32 \%)\end{array}$ & $\begin{array}{l}703.9 \\
(21 \%)\end{array}$ & $\begin{array}{c}590.95 \\
(17.60 \%)\end{array}$ & $\begin{array}{c}994.25 \\
(29.61 \%)\end{array}$ \\
\hline $\mathrm{S} / \mathrm{S}$ & $4,769.3$ & $\begin{array}{c}1681.4 \\
(35.3 \%)\end{array}$ & $\begin{array}{l}1393.4 \\
(29 \%)\end{array}$ & $\begin{array}{l}581.6 \\
(12 \%)\end{array}$ & $\begin{array}{l}1112.9 \\
(23 \%)\end{array}$ \\
\hline N/EAST & $8,305.5$ & $\begin{array}{l}1752.7 \\
(21 \%)\end{array}$ & $\begin{array}{l}2183 \\
(26 \%)\end{array}$ & $\begin{array}{l}609 \\
(7 \%)\end{array}$ & $\begin{array}{l}3760.8 \\
(45 \%)\end{array}$ \\
\hline N/CENT & $8,902.75$ & $\begin{array}{l}1750.3 \\
(19 \%)\end{array}$ & $\begin{array}{l}1490.5 \\
(16 \%)\end{array}$ & $\begin{array}{c}1642.25 \\
(18 \%)\end{array}$ & $\begin{array}{l}4019.7 \\
(45 \%)\end{array}$ \\
\hline S/WEST & $5,768.74$ & $\begin{array}{l}709.4 \\
(12 \%)\end{array}$ & $\begin{array}{c}2560.18 \\
(44 \%)\end{array}$ & $\begin{array}{l}951.75 \\
(16 \%)\end{array}$ & $\begin{array}{c}1547.405 \\
(26 \%)\end{array}$ \\
\hline N/WEST & 6,139 & $\begin{array}{l}2276.5 \\
(37 \%)\end{array}$ & $\begin{array}{c}2241 \\
(36 \%)\end{array}$ & $\begin{array}{c}1082 \\
(17 \%)\end{array}$ & $\begin{array}{l}539.5 \\
(8 \%)\end{array}$ \\
\hline TOTAL & 37242.29 & 9238.09 & 10571.98 & 5456.65 & $11,974.56$ \\
\hline$\%$ of Total & 100 & 24.81 & 28.39 & 14.7 & 32.2 \\
\hline
\end{tabular}

Source: FERMA 2013. All percentages computed by Authors.

El-Rufai (2011) provides an interesting catalogue of the woes and opportunities plaguing the Nigerian transportation sector, especially road infrastructure. He submits that by 2004, Nigeria had a total road length of $193,200 \mathrm{~km}$ as against South Africa's 362,000 as at 2002 . However, only about 15 percent of these roads are paved and 28 percent of them are not motorable, with over 5 million vehicles plying them. This overbearing pressure and overuse result in a staggering N450 billion being spent annually by Nigerian road users to repair their vehicles. Another recurring trait of our road infrastructure is the sheer costs of building and maintenance. Road projects in Nigeria suffer the triple curse of costs overruns, delays in completion and poor quality. 
Another manifestation of this decay is evidenced in the frequency of road accidents across the country. Nigeria is reputed to have the second highest rate of road accidents among 193 countries; and deaths from bad roads and reckless driving are the third leading cause of death in Nigeria (Vanguard, 2013). In 2012, at least 473 persons died from a total of 1,115 vehicular accidents nationwide. A study (Oluwasanmi, 2013) of road accident trends in Nigeria between the period 1960 and 1989 revealed a sharp increase in fatal accident occurrence. Between 1960 and 1969, it was observed that over 18,000 deaths occurred as a result of road accidents. By the third decade (1980-1989), this figure had increased to about five times, i.e. more than 92,000 deaths. Deplorable conditions of our roads are obviously cited as one of the reasons for the severity and frequency of road accidents in Nigeria. The Punch Newspaper (2012) quoting from the report of the Federal Road Safety Commission states that between January and June 2011 road accidents claimed 2,218 lives in 2,234 crashes, compared to 1,822 deaths in 2, 673 crashes in January-June 2010. "That 162 persons die per 100,000 in road accidents here has alarmed the World Health Organisation which says that, of the 1.3 million killed in road accidents worldwide each year and 50 million who suffer injuries, the developing nations account for 80 percent". This obviously is not unconnected to the poor state of road infrastructure.

\section{Overview of Policy Response to Road Infrastructure Challenge}

Several administrations have over the years proffered its own solution to the road infrastructure challenges facing the nation. The colonial administration is credited with opening up the rural and semi-urban centres and connecting them to the various administrative headquarters. These efforts were consolidated by the drawing up of various development plans which earmarked huge capital outlays for road infrastructure development across the country. From Table 2 we observe that in the First National Development Plan (1962-1968), provision for road infrastructure gulped about $21 \%$ of total plan expenditure. By the end of the Civil War, the Federal Government launched a second plan which thrust was the rehabilitation, reconstruction, reintegration of the war-torn areas. Thus provision for road infrastructure increased to about $24 \%$ of total plan expenditure. Evidence abound that it was during this period that many road projects as well as tertiary educational institutions were established across the country.

Table 2. Percentage share of the transport sector in Nigeria's public sector (1962-1998)

\begin{tabular}{lll}
\hline Plan & Plan Period & \% Share of Transport Sector \\
\hline First National Development Plan & $1962-1968$ & $21.3 \%$ \\
Second National Development Plan & $1970-1974$ & $23.7 \%$ \\
Third National Development Plan & $1975-1980$ & $22.2 \%$ \\
Fourth National Development Plan & $1981-1985$ & $15.2 \%$ \\
National Rolling Plan & $1993-1995$ & $11.0 \%$ \\
National Rolling Plan & $1994-1996$ & $8.6 \%$ \\
National Rolling Plan & $1996-1998$ & $10.1 \%$ \\
\hline
\end{tabular}

Source: $1^{\text {st }}, 2^{\text {nd }}, 3^{\text {rd }}$, and $4^{\text {th }}$ National Development Plans (1962-85) and the Rolling Plans (1993-98).

However, by the Third National Development Plan (1975-1980), signs of deprioritisation and indifference concerning the pivotal role of road infrastructure to Nigeria's economic development started emerging. Henceforth, budgetary and plan allocation to roads plummeted, so that by the 1994-96 rolling plan, the subsector only claimed about $8.6 \%$ of aggregate plan expenditure.

Matters got worse for the subsector during the SAP and the ensuing NEEDS era. With dwindling government revenues and avid implementation of neo-liberal policies of the SAP regime, adequate provision was not made for the construction, rehabilitation or the opening up of new roads. Even with the paltry vote for roads rehabilitation, the reality on the ground never reflected the amounts of funds released to the ministry of works (See, for instance Edame et al., 2011). Nor has the bidding process for public sector contracts helped in enhancing the efficiency of the sector. With government contracts biased against transparency and due process, huge funds voted for road infrastructure especially during the Obasanjo Administration could not be accounted for as the roads remained unrepaired and the decay ripened to obtrusive degeneration.

From Table 3 a trend is observed, namely, that transportation allocation was mostly skewed in favour of land transport, followed by water, then air. This priority was not maintained in subsequent plan periods. It is noteworthy in this regard that revenue allocation to the transport sector declined from about $22 \%$ in the $1960 \mathrm{~s}$ and 1970s to barely $10 \%$ during the earlier part of the 1990s, despite rapid growth rates in population and 
urbanisation and an ambitious industrialisation programme.

Table 3. Public sector planned investment on transport (1962-1985)

\begin{tabular}{|c|c|c|c|c|c|c|c|c|c|}
\hline \multirow[t]{2}{*}{ Plan Period } & \multirow[t]{2}{*}{ Plan Size } & \multirow{2}{*}{$\begin{array}{c}\text { Transport } \\
\text { Sector } \\
\text { Allocation }(\mathrm{Nm}) \\
\end{array}$} & \multicolumn{3}{|c|}{ Modal Distribution (Nm) } & \multicolumn{3}{|c|}{ Modal Distribution (\%) } & \multirow{2}{*}{$\begin{array}{l}\text { Transport } \\
\text { Sector as \% } \\
\text { of Plan Sizt }\end{array}$} \\
\hline & & & Land & Air & Water & $\begin{array}{l}\text { Land as \% of } \\
\text { Transp. Alloc. }\end{array}$ & $\begin{array}{c}\text { Air as \% of } \\
\text { Transp. Alloc. }\end{array}$ & $\begin{array}{l}\text { Water as \% of } \\
\text { Transp. Alloc. }\end{array}$ & \\
\hline $1962-1968$ & $1,586,000$ & 309,092 & 211,940 & 20,644 & 76,508 & 68.0 & 7.0 & 25.0 & 19.0 \\
\hline 1970-1974 & $2,050,738$ & 472,398 & 359,840 & 51,284 & & 76.0 & 11.0 & 13.0 & 23.0 \\
\hline $1975-1980$ & $43,314,009$ & $9,677,541$ & $8,025,453$ & 801,326 & 850,762 & 83.0 & 8.0 & 9.0 & 22.0 \\
\hline 1981-1985 & $70,500,000$ & $10,706,616$ & $9,091,992$ & 653,100 & 961,524 & 85.0 & 6.0 & 9.0 & 15.0 \\
\hline
\end{tabular}

Source: FRN, Fourth National Development Plan (1981-1985).

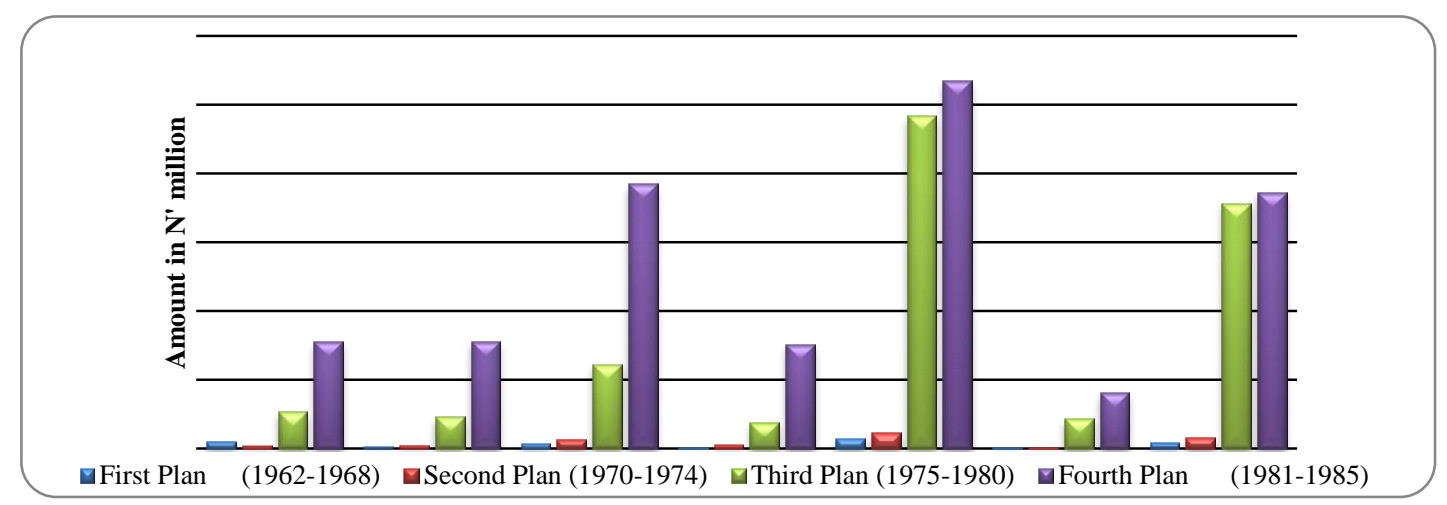

Figure 1. Public sector planned capital investment (Nm), 1962-1985

Table 4 presents an abridged version of paved and unpaved roads as a percentage of total roads in Nigeria (See Appendix B for the full table), and the graph that follows depicts the full data of the Table in the Appendix A. The period 1970-1979 and the subsequent three periods of 1980-1989, 1990-1999 and 2000-2009 show the aggregated percentage of roads paved and unpaved within a lag of ten years respectively. More recent data from 2010 to 2013 reveal that the percentage of paved roads was less that $20 \%$ of total roads in Nigeria. This further strengthens the thesis of decay and deprioritisation.

Table 4. Paved and unpaved roads in Nigeria as \% of total roads

\begin{tabular}{lrc}
\hline Year & Paved Roads & Unpaved Roads \\
\hline $1970-1979$ & 218.0 & 782.0 \\
$1980-1989$ & 268.0 & 732.0 \\
$1990-1999$ & 265.2 & 734.8 \\
$2000-2009$ & 219.6 & 780.4 \\
2010 & 19.5 & 80.5 \\
2011 & 19.0 & 81.0 \\
2012 & 18.6 & 81.4 \\
2013 & 18.1 & 81.9 \\
\hline
\end{tabular}

Source: World Bank 2012 and 2013 (World Development Indicators). Annual Abstract of Statistics (Various Issues) cited in Anyanwu, Oyefusi, Oaikhenan and Dimowo (1997, p. 335). 


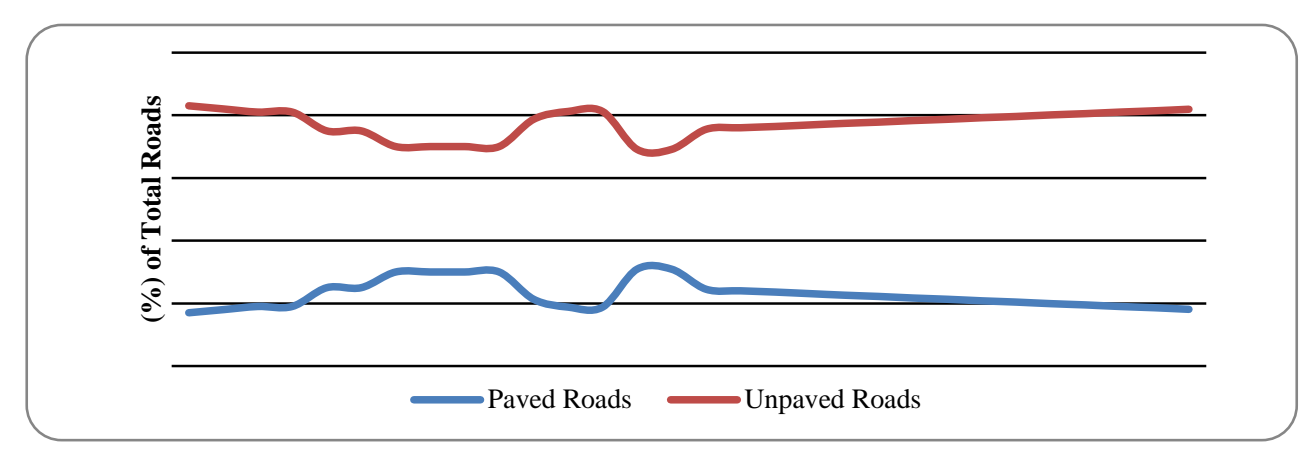

Figure 2. Paved and unpaved roads in Nigeria as \% of total roads

Of the percentage of paved roads, Umoren, Sule and Eni (2011), observed that in Nigeria, about $26 \%$ of the paved road network was in poor condition requiring rehabilitation and reconstruction while $42 \%$ was in fair condition that requires resurfacing to prevent further decline to poor conditions. According to him, the conditions of unpaved roads were even worsening.

A cursory appraisal of Appendix A reveals that the share of transport expenditure as share of GDP between 1970 and 2013 has not fared well during the period under review. It was a paltry 2.34 percent but marginally rose to 4.3 percent in 1975, deteriorating further to 2.4 percent in 1980. Its highest share in GDP was in 1981 where it posted $16.8 \%$ but sharply plummeted in subsequent years from 10.3 percent in 1983 to 0.05 percent in 2013 . Very significantly, even with the return to democratic rule in 1999 , the government at all levels paid less attention to the transport sector, an attitude which negatively affected the road transportation subsector. Thus annual budgetary allocation to the transport sector as a percentage of GDP was consistently less than one percent from 1993 to 2013.

It was in response to the enormous challenges of the transportation sector that the Federal Government set up FERMA in 2002 to monitor and maintain the federal road network. While it is within the province of the Highway Department of the Federal Ministry of Works to design and construct new highways, and to reconstruct and rehabilitate badly damaged ones, FERMA on its part is statutorily empowered to maintain the highways at acceptable levels of usability. In recent times however, FERMA has been severally accused of politicisation of its operations with stringent calls for its scrapping.

Government also pursued toll gate policies on its highways as a means of generating revenue for the maintenance of the roads. But like most government policies, this was sabotaged by manifest corruption, concealment and diversion of funds by the operators. The policy also bred negative social dimensions of long queues and travel bottlenecks. Toll gates were then used as outlets for criminality, prostitution, human trafficking, and illegal trading in drugs. Thus in 2004, the policy was scrapped and in its place a petroleum product tax was introduced.

Again, in view of the financing gap associated with funding road infrastructure, the Ministry of Works adopted a new paradigm known as the "Strategic Highway Investment for Transformation" (SHIFT). SHIFT was developed as a new plan to encourage public-private partnership in "Greenfield" projects.

\section{Infrastructure Gap}

A precise quantitative measure of Nigeria's infrastructure gap is as diverse as there are scholars and interested institutions. For example Sanusi (2012) asserts that Nigeria needs about N15 trillion to build infrastructure. Out of this figure, N3trillion is required for power, while rail tracks and roads are expected to gulp about N2trillion each, with oil and gas gulping the remaining N9trillion.With regards to sub-Saharan Africa generally, a recent study by the Pottas (2012) estimates that about US\$93-billion is needed annually over the next decade to overhaul sub-Saharan African infrastructure. About two-thirds or $\$ 60$-billion of that is needed for entirely new infrastructure and \$30-billion for the maintenance of existing infrastructure. Only about \$25-billion annually is being spent on capital expenditure, leaving a substantial shortfall that has to be financed.

A report by Africa Development Bank (AfDB, 2013) reveals that the country would require about $\$ 350$ billion over a period of 10 years to fully implement the proposed Infrastructure Action Plan (IAP), which is expected to address the current financing deficit. It believes that, to attain middle-income levels, Africa must double its investment in infrastructure. According to the Bank, such investment in infrastructure is expected to rise to a peak of 12 percent of Gross Domestic Product (GDP) by 2016 before falling to about 10 percent by 2020. African 
nations at present invest about 2-3 percent of gross domestic product (GDP) in infrastructure. By contrast, China invests about 9 percent of its GDP in infrastructure projects. India plans \$1 trillion in investments over the next five years to modernize its economy.

Ohiani (2013) quotes the World Economic Forum report as saying that though annual investment in infrastructure in Africa doubled from $\$ 17$ billion to $\$ 35$ billion between 2001 and 2009 , the overall infrastructure spending needs for sub-Saharan Africa is estimated at $\$ 93$ billion annually over the next decade. Thus this overbearing fiscal burden on government is huge considering the fact that as the sole financier of infrastructure projects, it has often taken responsibility for construction, operations and maintenance, with the national fiscal budget being the principal source of financing infrastructure development.

Yari (2010) opines that Nigeria's huge Infrastructure deficit would require $\$ 12 b$ to $\$ 15 b$ annually for the next 5 to 6 years as FGN's annual Capital Budget can only cover a fraction. Between 1999 and 2007, the Nigerian government spent about $\mathrm{N} 2$ trillion through direct budgetary allocations on basic infrastructure in agriculture and water resources, transportation, education, health, power generation and distribution, with an annual infrastructure investment gap of $\$ 31$ billion still begging to be filled (Ohiani, 2013). Such expenditure is however unsustainable in the medium and long term in view of the declining fiscal receipts and the competing demands of same on government.

Yet, Akinyosoye (2010), referring to Asian Development Bank report, maintains that a country's infrastructure development should amount to a minimum of $6 \%$ of GDP to attain a reasonable level of sustainable development. He argues that Nigeria's infrastructure spending contributed a meagre $1.9 \%$ / annum to GDP over the last decade. Thus for Nigeria to bridge the gap and reach average levels of annual growths recorded amongst Asian countries, infrastructure spending (as a percentage of GDP) must increase to $18 \%$ to bridge the gap (with Asia) in 15 years and $24 \%$ in 10 years. He asserts further that for Nigeria to attain or surpass average growth rates of Asian countries, contribution of infrastructure to GDP has to increase by a factor of 9 in "tangible" 10 spending (i.e. from $1.9 \%$ to $18 \%$ /annum) over 15 years; and to achieve that over 10 years, it will require increased infrastructure spending by a factor of 12 (i.e. from $1.9 \% 11$ to $24 \%$ ) per annum.

In spite of these disparate data on the existing infrastructure gap and the quantum of investment required, one thing can be generalised from these analysis, namely that Nigeria, and indeed sub-Saharan Africa's infrastructure needs are huge. Thus failure to map out pragmatic and strategic financing options for the sector will only guarantee further infrastructural deterioration. Such financing options must take into considerations parameters such as cost efficiency, equity, allocation efficiency and fiscal prudence. The next section takes a look at options available to government.

\section{Financing Options}

We dichotomise financing alternatives into short and long term options. The former involves immediate solutions and policy choices that government can make in order to urgently address infrastructure emergency; the latter deals with the issue of sustainability. Short term policy options include the use of sovereign wealth fund, pension funds, foreign reserves, the AGOA mechanism, public private partnerships, and savings from the reduction in fuel subsidy. In the long term however, government must confront the hard road of increased allocation to the states and local governments as an enduring platform for infrastructure provision and sustainability. In effect, while the short term deals with the matter of urgency, the long term that of durability and sustainability. Figure 3 below is a schematic representation of a portfolio of financing options available for government. 


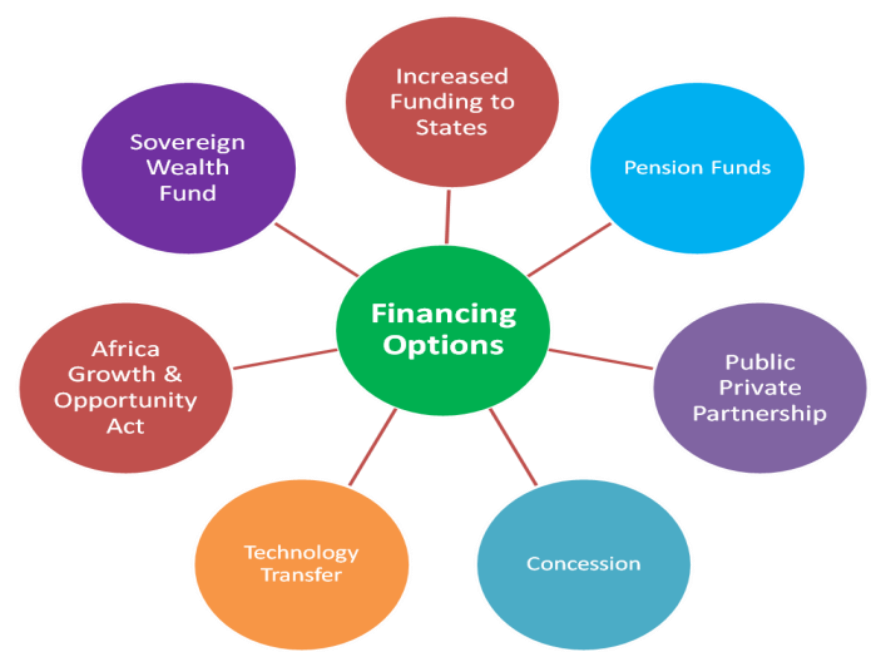

Figure 3. Financing options for infrastructure development

\subsection{Increased Funding for Component Units}

In section 3 above, reference was made to the fact that Nigeria has the largest road network in West Africa and the second largest South of the Sahara. Sanusi (2012) estimates that the total road network in Nigeria stands at 194, $800 \mathrm{~km}$. Of this, the Federal Government is responsible for 22 percent of roads, while the state and local governments are responsible for 27 percent and 51 percent of road kilometres, respectively. Discounting the portion of the federal government, it means that both the states and local governments must shoulder the burden of constructing, repairing and managing the 78 percent of roads in Nigeria. This is both weird and unrealistic in view of the fact that in the fiscal distribution of national revenue, the FG alone retains 52.68 percent, while states and local governments receive 26.72 percent and 20.60 percent respectively. This explains why most of the roads are in a terrible state. For instance, the Calabar-Itu, Calabar-Ikom-Ogoja and the Ikot Ekpene-Aba roads have over the years become a nightmare for road users, with reported cases of accidents every day. Yet these are federal roads being hosted by both Cross River and Akwa Ibom States. The latter has resorted to repairing them to be reimbursed later by the Federal Government.

The reasoning is that these so-called federal roads are indeed being used, not by foreign elements but, by indigenes of the host states who suffer the brunt of their continued neglect. Abuja is far removed from the grassroots, and therefore does not feel the pulse and scars decayed infrastructure have left on the psyche of citizens. The States and Local governments on the other hand are better positioned to know the strategic needs of their people. It is therefore illogical for the Federal Government to claim over 50\% of federation revenue and yet not able to deliver on basic services to the citizenry. An increase in the statutory allocation to the states and local governments would ensure that component units of the federation control more resources to deploy and develop infrastructure in their immediate domain. This advocacy would require progressive amendments to extant fiscal legislations as well as increasing the technical capacity of the local governments in road transport infrastructure management.

\subsection{Sovereign Wealth Fund}

These are state-owned funds which exist for investment purposes. They are composed of financial assets such as stocks, bonds, property, precious metals, or other financial instruments. Their creation is informed by budgetary surpluses by the government and the realisation that oil resource revenues (as in the case of Nigeria) suffer from high price volatility, unpredictability of extraction, and exhaustibility. Again it is not always wise to hold such surpluses in the form of money. Presently, with the inauguration of the board of the Nigeria Sovereign Investment Authority (NSIA), a total of $\$ 200$ million has been allocated to the Stabilisation Fund, $\$ 325$ million to the Future Generation Fund, while $\$ 325$ million has been allocated to the Nigerian Infrastructure Fund (Leadership, 2013). However, the infrastructure funds, for instance, is to be invested in areas of commercial infrastructure where the investment will yield returns, estimated at about 6 or 7 percent. Expectedly, from the benefit of hindsight in the telecom industry revolution, Nigerians would not mind paying for such infrastructure so long as the social marginal utility therefrom exceeds costs from consumption. Thus, sovereign wealth fund is a veritable short term option policy makers should look into as ways of bridging the infrastructure gap. 


\subsection{Pension Funds}

Like the sovereign wealth fund, the pension funds are another veritable avenue through which government can source for funds at affordable interest rates to finance infrastructure in Nigeria. As at June, 2013, the value of pension cash saved under the Contributory Pension Scheme rose to N3.4 trillion (Uduanu, 2013), just nine years after its introduction, while no fewer than 5.5 million workers have opened Retirement Savings Accounts with Pension Fund Administrators. With proper institutional mechanism coupled with relevant capacity building measures, such huge funds can be efficiently managed to the benefit of the economy, instead of warehousing them into idleness. Studies by Canning and Fay (1993) and Akinyosoye (2010) show that developing countries have a high rate of return to infrastructure comparable to developed ones. Conclusive evidence linked increased output to increased investment in transport infrastructure, though not immediate. Our advocacy here is that the use of pension funds (which by their nature are long term financing instruments) to finance infrastructure investment is, in our specific circumstance, likely to yield positive multiplier effects as returns on them would be able to repay both interest and principal in the long run.

\subsection{Africa Growth and Opportunity Act}

This is a trade preference platform initiated by the US government to about 40 sub-Saharan African nations that are making progress in economic and political reforms. Since its establishment in 2004, trade between the two parties has grown to $\$ 82.1$ billion in 2010; AGOA exports to United States have increased to $\$ 44.3$ billion. Exports from sub-Saharan Africa in 2011 amounted to $\$ 74.2$ billion with Nigeria topping the list with $\$ 33.7$ billion mainly from crude oil sales and Chad at the bottom of the list with $\$ 3.1$ billion also from crude oil sales (USDSBIIP, 2012). The US government is keen to developing strategic infrastructure within the ambience of AGOA that encourages trade between the two parties; and the Nigeria government can initiate ways in which she can maximise the opportunities provided by AGOA.

\subsection{Public Private Partnership (PPP)}

Several reasons account for the increasing calls for governments in developing nations to rely on PPP as an alternative mechanism to subsisting traditional approaches in the provision of infrastructure. These orthodox approaches include the design-bid-build mechanism which features the dominant role of the owner (i.e. Public sector). Thus much of the risk is held by the owner from the project conceptual stage, through project finance up to operation, maintenance and ownership.

First, PPP allows governments to free up fiscal funds for use in other pressing areas. Second, there are risks inherent in the use of traditional approaches of procurement which are often in the areas of schedule completion, delays and cost overruns. Other risks include poor maintenance cultures of governments which discourage efficiency and hasten the decay of infrastructure. Third, Akinyosoye (2010) also contemplates a financial risk which manifest in excessive advance payment (mobilization) to contractors. This places a huge risk on public funds in the light of weak public institutional capacity to monitor and provide contractual oversight. Fourth, PPP encourages post construction service. Firms who build the infrastructure are obliged to maintaining them even after construction - (see for instance Uff, 2005). Fifth, Foster and Briceno-Garmendia (2010) also identify long term revenue generation risks in the traditional approaches due to under-collection. This is evident in inefficient government run infrastructures like the power sector, with the consequence of inadequate funding for operations and maintenance.

In effect, because of the above reasons, the PPP model is gaining currency globally because it enables both parties to optimally share risks involving infrastructure provision. Government in particular can then concentrate on areas it has comparative advantage (e.g. policy making and planning), while funding, development and operations of assets are left to the private sector deemed to be more innovative and efficient in managing them. Thus policy makers can adopt and integrate any of the variants of PPP into its financing strategies. These variants come in the form of BOOT (Build, Operate, Own, Transfer) or BOT (Build, Operate, Transfer) or DBFO (Design, Build, Finance, Operate). This is where bilateral and multilateral funding assistance can be of relevance. In the light of this, the FGN has recently signed an infrastructure deal with China.

\subsection{Concessions}

Broadly speaking, concessions may refer to any arrangement in which a firm obtains from the Government the right to provide a particular service for an agreed period of time. An old innovation dating back to the nineteenth century, concessions have proven efficient in regulating natural monopolies and may not necessarily confer legal monopoly when the necessary clauses are incorporated (and enforceable) in the concession agreement. In this regard, government has significant roles to play. These include adopting legal frameworks and provisions to 
enable the granting of concessions based on knowledge of local needs and priorities; project identification and analysis; granting permits and other necessary authorizations; design of the concession arrangements e.g. legal instrument, pricing rules, performance targets, duration and termination etc.; concession award, which includes choosing the method of award, bid structure and evaluation, bidding rules and procedures, negotiating etc.; and the exercise of regulatory function: supervising and monitoring as well as enforcing rules.

\subsection{Technology Transfer}

Technology transfer involves the movement of innovations, knowledge, and techniques from the originator to a secondary user, especially from developed to developing countries in an attempt to boost their economic development. In no other sector is this concept required better than in infrastructure provision. This is however a long term strategy and is conditioned on the following factors: (a) vision and commitment of government; (b) skills and training; (c) attracting export-oriented foreign direct investment; (d) support for local industry, and (e) local technology efforts in terms of research and development.

\section{Conclusion}

It is common knowledge that Nigeria's road infrastructure and indeed the general infrastructure of the entire sub-Saharan Africa, is in a most despicable condition. This paper formalises this observation by providing concrete, current data to support the assumptions. By deploying descriptive and theoretical methodological approaches, it demonstrates that road infrastructure is not only deteriorating but also suffers from a twin evil of deficit and deprioritisation in the public sector's preferential scale-a state of indifference of sorts. Long and short term policy choices have to be made to urgently address the issue. In the short term, infrastructure concessions, public private partnerships (PPP), pension funds, sovereign wealth fund, savings from reduction in fuel subsidies, leveraging on the AGOA mechanism-are part of the portfolio of choices that government can readily choose from. In the long term however, the paper recommends a strategic policy of incremental transfer of technology from the West and an increase in the statutory allocations to the sub-national units within the Nigerian Federation, the aim being to empower the states and local governments to deal promptly to road infrastructure challenges within their jurisdiction.

\section{References}

Aderamo, A. J. (2012). Transport Infrastructure and The Nigerian Environment: A Review. International Review of Business and Social Sciences, 1(6).

AfDB. (2013). Africa Development Bank Monthly Nigeria Field Office (NGFO) Newsletter for June in THISDAY Newspaper, $14^{\text {th }}$ June, 2013.

Agénor, P. (2009). Public Capital, Growth, and Welfare. Book in progress, University of Manchester (December 2009).

Agénor, P., \& Kyriakos, N. (2006). The Allocation of Public Expenditure and Economic Growth. Working Paper No. 69, Centre for Growth and Business Cycle Research, University of Manchester. Forthcoming, Manchester School of Social and Economic Studies.

Agénor, Pierre-Richard. (2010). A Theory of Infrastructure-Led Development.

Akinwale, A. A. (2010). The Menace of Inadequate Infrastructure in Nigeria. African Journal of Science, Technology, Innovation and Development, 2(3), 207-228.

Akinyosoye, M. (2010). Infrastructure Development In Nigeria Road Map To Sustainable Development. Working Paper.

Aluede, O., Idogho, P. O., \& Imonikhe, J. S. (2012). Increasing Access To University Education In Nigeria: Present Challenges And Suggestions For The Future. The African Symposium: An online journal of the African Educational Research Network, 12(1), June 2012.

Anyanwu, J. C., Oyefusi, A., Oaikhenan, H., \& Dimowo, F. A. (1997). The structure of the Nigerian economy: 1960-1997. Onitsha: Joanee Educational Publishers Ltd.

Buhari, M. (2000). The Role of Infrastructural Development and Rehabilitation in Sustainable Economic Growth in Nigeria. Paper presented at the All Peoples Party Economic Summit held at Ladi Kwali Conference Centre, Sheraton Hotel and Towers Abuja, 9th - 10th November, 2000.

Edame, G. E., Fonta, W. M., Edet, E. O., \& Henshaw, V. E. (2011). Public Expenditure, Infrastructure and Industrial Growth Drivers in Nigeria: A Vector Auto Error Correction Specification. In Industrial Development: A Catalyst for Rapid Economic Growth (pp. 151-170). P. N. Davidson Publications. 
El-Ruffai, N. (2011). Nigeria's Infrastructure Deficit in Business Day Newspaper, $15^{\text {th }}$ July, 2011.

Ezeabasili, V. N., Isu, H. O., \& Mojekwu, J. N. (2011). Nigeria's External Debt and Economic Growth: An Error Correction Approach. International Journal of Business and Management, 6(5). http://dx.doi.org/10.5539/ijbm.v6n5p156

Foster, V., \& Briceno-Garmendia, C. (2010). Africa's Infrastructure: A time for Transformation. Washington, D.C.: The World Bank.

Frischmann, B. M. (2007). An Economic Theory of Infrastructure and Commons Management. Minnesota Law Review.

Gungul, T. T. (2012). Road Traffic Accidents in Nigeria: Causes and Control. Journal of Applied Science and the Environment, 3, 25-29.

Jorgenson, D. (2001). Fragile Statistical Foundations: The Macroeconomics of Public Infrastructure Investment. American Enterprise Institute Discussion Paper, February.

Leadership Newspapers $\quad$ Group. (2013). $\quad$ Retrieved from http://leadership.ng/news/210513/investment-sovereign-wealth-fund-starts-june-200

Ohiani, J. (2013). Governmental Promotion of Infrastructure Development. Paper Presented by the Head, Legal and Governance Department, Infrastructure Concession Regulatory Commission (ICRC), at the inaugural ESQ Project Finance Summit, held in Lagos, 2013.

Okonjo-Iweala, N., Soludo, C., \& Murkthar, M. (2003). The Debt Trap in Nigeria: Towards Sustainable Debt Strategy. Debt Management Office, Nigeria.

Oluwasanmi, A. J. (2013). Road Accident Trends In Nigeria. Department of Mechanical Engineering, University of Benin, Nigeria.

Pottas, A. (2012). Addressing Africa's Infrastructure Challenges. Deloitte Corporate Finance, (ICA) Infrastructure Consortium Africa. Retrieved from http://www.deloitte.com

Punch Newspaper. (2012). Editorial August 26, 2012, Alarming Rate Of Road Accidents.

Sanusi, S. L. (2012). Infrastructure, Industrialisation and the Nigerian Economy. Paper Presented At The Second Public Lecture of Kresta Laurel Limited in Lagos.

Tella, S. A., Amaghionyeodiwe, I. A., \& Adesoye, B. A. (2007). Telecommunications Infrastructure and Economic Growth: Evidence from Nigeria.

Todaro, M. P., \& Smith, S. C. (2009). Economic Development (10th ed.). Pearson Education Limited, England.

Ubi, P. S., Eke, F. A., \& Oduneka, A. E. (2011). The Role of Infrastructure in Industrialisation of a Developing Economy: the Case of Electricity Supply and Education in Nigeria. In E. Udoh, U. R. Ogbuagu, \& U. Essia (Eds.), Industrial Development: A Catalyst for Rapid Economic Growth. P.N. Davison Publications, Nigeria.

Uduanu, D. (2013). Contributory Pension Scheme Assets Rise To N3.4tn. Punch Newspaper, June 10, 2013.

Uff, J. (2005). Construction Law (9th ed.). Swiss Cottage, London: Sweet \& Maxwell Limited.

Umoren, V., Sule, R. O., \& Eni, D. D. (2011). Assessment of some road infrastructure in Akwa Ibom State, Nigeria. Ethiopian Journal of Environmental Studies and Management, 4(2), 83-87.

Urban Development Bank. (2013). Retrieved from http://www.udbng.com

USDSBIIP. (2012). United States Department of State Bureau of International Information Programs.

Vanguard Editorial. (2013). Road Accidents - More Causes For Alarm.

Wagsta, A., \& Cleason, M. (2004). The Millennium Development Goals for Heath: Rising to the Challenges. World Bank, Washington DC.

Wang, L. (2003). Determinants of Child Mortality in LDCs: Empirical Findings from Demographic and Health Surveys. Health Policy, 65, 277-299. http://dx.doi.org/10.1016/S0168-8510(03)00039-3

World Bank. (2012). World Development Indicators (2012). Washington: DC: The World Bank.

World Bank. (2013). World Development Indicators (2013). Washington, DC: The World Bank.

Yari, K. M. (2010). Financial and Contractual Arrangement for a sustainable Infrastructure Concession: Financiers' Perspective. Seminar on "Infrastructure Concession: A Tool for Sustainable Economic Stability, 
Prospect and Challenges" Abuja, 14-15th April, 2010.

Yoshino, Y. (2008). Domestic Constraints, Firm Characteristics, and Geographical Diversification of Firm-Level Manufacturing Exports in Africa. Policy Research Working Paper No. 4575, World Bank. http://dx.doi.org/10.1596/1813-9450-4575

\section{Appendix A}

Transport share of GDP at current factor cost between 1970 and 2013 in $\mathbf{A m}$

\begin{tabular}{|c|c|c|c|c|c|c|c|}
\hline \multirow[t]{2}{*}{ Year } & \multicolumn{5}{|c|}{ Mode of Transport } & \multirow{2}{*}{$\begin{array}{l}\text { GDP at current } \\
\text { market prices }\end{array}$} & \multirow{2}{*}{$\begin{array}{c}\text { Transport as \% } \\
\text { Total GDP }\end{array}$} \\
\hline & Transport & Road & Rail \& Pipelines & Water & Air & & \\
\hline 1970 & 123.50 & 73.00 & 17.40 & 26.90 & 6.20 & $5,281.10$ & 2.34 \\
\hline 1971 & 150.00 & 100.50 & 13.80 & 30.70 & 5.00 & $6,650.90$ & 2.26 \\
\hline 1972 & 186.80 & 133.60 & 15.30 & 31.50 & 6.40 & $7,187.50$ & 2.60 \\
\hline 1973 & 199.80 & 142.40 & 14.80 & 30.00 & 12.60 & $8,630.50$ & 2.32 \\
\hline 1974 & 554.58 & 554.58 & 93.60 & 1.59 & 8.40 & $18,823.10$ & 2.95 \\
\hline 1975 & 920.30 & 920.30 & 108.28 & 75.52 & 44.62 & $21,475.24$ & 4.29 \\
\hline 1976 & 835.17 & 835.17 & 122.96 & 149.45 & 80.84 & $26,655.78$ & 3.13 \\
\hline 1977 & 987.13 & 987.13 & 137.64 & 223.38 & 117.06 & $31,520.34$ & 3.13 \\
\hline 1978 & $1,017.65$ & $1,017.65$ & 152.32 & 297.31 & 153.28 & $34,540.10$ & 2.95 \\
\hline 1979 & 969.14 & 969.14 & 167.00 & 371.24 & 189.50 & $41,974.70$ & 2.81 \\
\hline 1980 & $1,168.21$ & $1,168.21$ & 181.68 & 445.17 & 225.72 & $49,632.32$ & 2.35 \\
\hline 1981 & $7,981.85$ & $6,718.52$ & 196.36 & 580.14 & 261.94 & $47,619.66$ & 16.76 \\
\hline 1982 & $6,292.03$ & $5,085.18$ & 211.04 & 470.95 & 298.16 & $49,069.28$ & 12.82 \\
\hline 1983 & $5,448.76$ & $4,000.10$ & 191.17 & 728.00 & 316.26 & $53,107.38$ & 10.26 \\
\hline 1984 & $5,023.44$ & $3,857.77$ & 195.64 & 485.81 & 309.50 & $59,622.53$ & 8.43 \\
\hline 1985 & $5,988.56$ & $4,945.99$ & 143.38 & 413.31 & 318.46 & $67,908.55$ & 8.82 \\
\hline 1986 & $5,267.00$ & $4,378.71$ & 138.36 & 307.35 & 268.34 & $69,146.99$ & 7.62 \\
\hline 1987 & $5,268.71$ & $4,431.25$ & 102.30 & 288.14 & 271.03 & $105,222.84$ & 5.01 \\
\hline 1988 & $5,320.91$ & $4,484.43$ & 79.80 & 318.62 & 260.33 & $139,085.30$ & 3.83 \\
\hline 1989 & $5,332.18$ & $4,574.13$ & 58.73 & 275.29 & 243.66 & $216,797.54$ & 2.46 \\
\hline 1990 & $5,438.84$ & $4,665.62$ & 59.91 & 280.80 & 248.53 & $267,797.54$ & 2.03 \\
\hline 1991 & $5,620.68$ & $4,852.25$ & 47.43 & 282.00 & 252.26 & $312,139.74$ & 1.80 \\
\hline 1992 & $5,880.47$ & $5,143.38$ & 34.15 & 256.37 & 247.32 & $532,613.83$ & 1.10 \\
\hline 1993 & $6,143.80$ & $5,400.55$ & 27.08 & 290.22 & 206.77 & $683,869.79$ & 0.90 \\
\hline 1994 & $6,179.31$ & $5,481.55$ & 1.25 & 261.20 & 186.10 & $899,863.22$ & 0.69 \\
\hline 1995 & $6,289.54$ & $5,536.36$ & 0.93 & 274.27 & 188.90 & $1,933,211.55$ & 0.33 \\
\hline 1996 & $6,457.61$ & $5,647.08$ & 1.02 & 282.50 & 194.57 & $2,702,719.13$ & 0.24 \\
\hline 1997 & $6,685.92$ & $5,816.40$ & 1.13 & 289.57 & 196.51 & $2,801,972.58$ & 0.24 \\
\hline 1998 & $6,974.29$ & $6,019.98$ & 1.18 & 293.92 & 200.44 & $2,708,430.86$ & 0.26 \\
\hline 1999 & $7,256.69$ & $6,200.57$ & 1.24 & 298.91 & 205.45 & $3,194,014.97$ & 0.23 \\
\hline 2000 & $7,508.13$ & $6,392.79$ & 1.29 & 305.84 & 213.65 & $4,582,127.29$ & 0.16 \\
\hline 2001 & $7,858.42$ & $6,667.68$ & 1.36 & 313.18 & 222.19 & $4,725,086.00$ & 0.17 \\
\hline 2002 & $9,226.37$ & $7,910.27$ & 1.41 & 287.87 & 264.46 & $6,912,381.25$ & 0.13 \\
\hline 2003 & $9,338.02$ & $8,003.68$ & 1.48 & 286.67 & 283.97 & $8,487,031.57$ & 0.11 \\
\hline 2004 & $13,993.70$ & $12,580.64$ & 1.57 & 303.58 & 300.72 & $11,411,066.91$ & 0.12 \\
\hline 2005 & $14,882.05$ & $13,385.91$ & 1.67 & 321.49 & 318.17 & $14,572,239.12$ & 0.10 \\
\hline 2006 & $15,911.46$ & $14,319.51$ & 1.77 & 340.87 & 342.16 & $18,564,594.73$ & 0.09 \\
\hline 2007 & $17,017.60$ & $15,323.40$ & 1.89 & 361.47 & 368.03 & $20,657,317.66$ & 0.08 \\
\hline 2008 & $18,204.25$ & $16,400.63$ & 2.00 & 383.34 & 395.96 & $24,296,329.29$ & 0.07 \\
\hline 2009 & $19,447.18$ & $17,534.51$ & 2.12 & 405.05 & 427.32 & $24,794,238.66$ & 0.79 \\
\hline 2010 & $20,752.69$ & $18,727.95$ & 2.24 & 426.82 & 458.73 & $29,205,782.96$ & 0.07 \\
\hline 2011 & $22,154.04$ & $20,010.70$ & 2.37 & 450.40 & 492.41 & $37,543,654.70$ & 0.06 \\
\hline 2012 & $23,555.38$ & $21,293.46$ & 2.50 & 473.99 & 526.10 & $40,544,099.94$ & 0.06 \\
\hline 2013 & $24,956.73$ & $22,576.21$ & 2.63 & 497.57 & 559.78 & $48,252,380.00$ & 0.05 \\
\hline
\end{tabular}

Source: CBN Statistical Bulletin, 2000 and 2013. 


\section{Appendix B}

Paved and Unpaved Roads in Nigeria as \% of total Roads

\begin{tabular}{|c|c|c|}
\hline Year & Paved Roads & Unpaved Roads \\
\hline 1970 & 17.0 & 83.0 \\
\hline 1971 & 18.0 & 82.0 \\
\hline 1972 & 19.0 & 81.0 \\
\hline 1973 & 19.0 & 81.0 \\
\hline 1974 & 21.0 & 79.0 \\
\hline 1975 & 23.0 & 77.0 \\
\hline 1976 & 25.0 & 75.0 \\
\hline 1977 & 25.0 & 75.0 \\
\hline 1978 & 25.0 & 75.0 \\
\hline 1979 & 26.0 & 74.0 \\
\hline 1980 & 25.0 & 75.0 \\
\hline 1981 & 26.0 & 74.0 \\
\hline 1982 & 27.0 & 73.0 \\
\hline 1983 & 27.0 & 73.0 \\
\hline 1984 & 27.0 & 73.0 \\
\hline 1985 & 25.0 & 75.0 \\
\hline 1986 & 26.0 & 74.0 \\
\hline 1987 & 28.0 & 72.0 \\
\hline 1988 & 28.0 & 72.0 \\
\hline 1989 & 29.0 & 71.0 \\
\hline 1990 & 30.0 & 70.0 \\
\hline 1991 & 30.0 & 70.0 \\
\hline 1992 & 30.0 & 70.0 \\
\hline 1993 & 30.0 & 70.0 \\
\hline 1994 & 21.3 & 78.7 \\
\hline 1995 & 18.8 & 81.2 \\
\hline 1996 & 18.8 & 81.2 \\
\hline 1997 & 30.9 & 69.1 \\
\hline 1998 & 30.9 & 69.1 \\
\hline 1999 & 24.5 & 75.5 \\
\hline 2000 & 24.0 & 76.0 \\
\hline 2001 & 23.6 & 76.4 \\
\hline 2002 & 23.1 & 76.9 \\
\hline 2003 & 22.6 & 77.4 \\
\hline 2004 & 22.2 & 77.8 \\
\hline 2005 & 21.7 & 78.3 \\
\hline 2006 & 21.3 & 78.7 \\
\hline 2007 & 20.8 & 79.2 \\
\hline 2008 & 20.4 & 79.6 \\
\hline 2009 & 19.9 & 80.1 \\
\hline 2010 & 19.5 & 80.5 \\
\hline 2011 & 19.0 & 81.0 \\
\hline 2012 & 18.6 & 81.4 \\
\hline 2013 & 18.1 & 81.9 \\
\hline
\end{tabular}

Source: World Bank 2012 and 2013 (World Development Indicators).

Annual Abstract of Statistics (Various Issues) cited in Anyanwu, Oyefusi, Oaikhenan, and Dimowo (1997, p. 335).

\section{Copyrights}

Copyright for this article is retained by the author(s), with first publication rights granted to the journal.

This is an open-access article distributed under the terms and conditions of the Creative Commons Attribution license (http://creativecommons.org/licenses/by/3.0/). 